\title{
The Impact of Banking Reforms on the Profitability of Nigerian Banking Industry
}

\author{
Echekoba, F.N. ${ }^{1}$, Egbunike, Chinedu Francis ${ }^{2}$, Gideon Ezu Kasie ${ }^{3}$ \\ ${ }^{1}$ Department of Banking \& Finance, Faculty of Management SciencesNnamdi Azikiwe University, P.M.B. 5025, \\ Awka, Nigeria \\ ${ }^{2}$ Department of Accountancy, Faculty of Management SciencesNnamdi Azikiwe University, P.M.B. 5025, Awka, \\ Nigeria \\ ${ }^{3}$ Department of Banking \& Finance, Faculty of Management SciencesNnamdi Azikiwe University, P.M.B. 5025, \\ Awka, Nigeria
}

\begin{abstract}
The recent reform in the Nigerian Banking system especially the consolidation exercise brought lots of changes into the financial system of Nigeria and had influence on bank interest rates, competition and transmission mechanism of monetary policy in so far as the increase in size and the opportunity for reorganization involved may either provide gains in efficiency that bear on marginal costs or give rise to increase in market power, or both together. The reform was introduced because of low capitalization, liquidation of banks, poor public perception, bank frauds, inability to attract or retain skilled manpower, poor remuneration and low investment in information technology and other major obstacles in the development and growth of banks in Nigeria. In spite of the steady growth of the local market, the Nigerian banking industry was underperforming when compared to Banking industries of other countries. Therefore, this study sought to examine the impact of the recent banking consolidation on the merger of UBA and Standard Trust PLCs and determine the impact of Bank share capital on the profitability of the banks before and after consolidation; determine the impact of the bank share capital on the total net asset of the Banks before and after consolidation and examine the relationship between Bank share capital and the ability of the Bank to grant loans and advances before and after consolidation. The study adopted the expost facto research design to enable the use of secondary data for the period 2001-2005 pre-merger and 2006-2010 post mergers where Bank Share capital (BSC) was the independent variable and Profit after Tax (PAT), Total Net Assets (TNA) and Loans and Advances (LA) were the dependent variables.
\end{abstract}

Keywords: Capital market ,Loans and Advances, Reforms , Banking and Monetary policy.

\section{Background of the Study}

Banks are the linchpin of the economy of any country. They occupy central position in the country's financial system and are essential agents in the development process. By intermediating between the surplus and deficit savings' units within an economy, banks mobilize and facilitate efficient allocation of national savings, thereby increasing the quantum of investments and hence national output (Afolabi, 2004). Through financial intermediation, banks facilitate capital formation (investment) and promote economic growth.

The decade 1995 and 2005 were particularly traumatic for the Nigerian banking industry; with the magnitude of distress reaching an unprecedented level, thereby making it an issue of concern not only to the regulatory institutions but also to the policy analysts and the general public (Nnanna, 2004). Thus the need for a drastic overhaul of the industry was quite apparent. In furtherance of this general overhauling of the financial system, the Central Bank of Nigeria introduced major reform programmes that changed the banking landscape of the country in 2004. The main thrust of the 13-point reform agenda was the prescription of minimum shareholders' funds of N25 billion for Nigerian Deposit money bank not later than December 31, 2005. In view of the low financial base of these banks, they were encouraged to merge. Out of the 89 banks that were in operation before the reform, more than 80 percent (75) of them merged into 25 banks while 14 that could not finalized their consolidation before the expiration of deadline were liquidated (Oladepo, 2010).

Moreover, while there are myriads of studies on the effects of consolidation on other sectors of the developing economies, there is paucity of studies on the effects of bank consolidation in developing countries like Nigeria.

It is therefore worth evaluating whether the banking reforms through consolidation have actually enhanced the growth of Nigerian Banks five years after the concluded exercise in enhancing their financial intermediating roles therefore this study aims to fill a gap by examining the impact of the reforms on profitability, total net assets and the ability of banks to grant credit to its customers, 


\section{Statement of the Problem}

As was the case before 1999, factors such as low capitalization, liquidation of banks, poor public perception, bank frauds, inability to attract or retain skilled manpower, poor remuneration and low investment in information technology have remained the major obstacles in the development and growth of banks in Nigeria (Lemo, 2005). In spite of the steady growth of the local market, the Nigerian banking industry has been underperforming when compared to Banking industries of other countries.

Therefore, there was the need for reforms which aimed at strengthening the asset based of Nigerian Banks as well as repositioning these banks in line with global practices and take advantage of size to enhance the value of the banks.

As it were the problem this research tries to solve anchored on the effect of the reforms on the profit potential and asset base of Nigerian banks before and after the consolidation exercise. This is the lacuna that this research seeks to fill.

\section{Objectives of the Study}

As a result of the problems associated with the reforms in the banking sector, the primary objectives of this study are:

1) To determine the impact of Bank share capital on the profitability of the Nigerian banks before and after consolidation

2) To determine the impact of bank share capital on the total net asset of the Nigerian Banks before and after consolidation

3) To examine the relationship between Bank share capital and the ability of Nigerian Bank to grant loans and advances before and after consolidation.

\section{Research Hypotheses}

The following Hypotheses were formulated;

$\mathbf{H}_{\mathbf{0 1}}$ : Bank share capital does not have a significant positive impact on profit after tax before and after consolidation

$\mathbf{H}_{\mathbf{0 2}}$ : $\quad$ Bank share capital does not have a significant positive impact on total net Assets of Nigerian banks before and after consolidation

$\mathbf{H}_{\mathbf{0 3}}$ : There is no positive relationship between bank share capital and loans and Advances of Nigeria Banks before and After Consolidation

Scope of the Study: The study covers the period 2001 to 2010 and it is divided into two periods, the period before the consolidation exercise 2001-2005 and the period after consolidation 2006-2010. The nature of this research work deals with the reformation in the Nigerian banking sector.

Limitations of the Study: The researcher no doubt was faced with numerous issues more especially during the collecting and collating of data. As most data obtained was through the internet, most times it is very difficult to get to a particular website for information as a result of using a slow server.

\section{Review Of Related Literature}

The Pre Reform/Pre-Consolidation Period:Prior to the noble idea of embarking on the overdue banking reform, there were lots of discordant operations by banks. The numbers of banks were large and yet production was unsatisfactory. By 2003 there were about eighty-nine (89) banks and tout of this number 7 were appointed as settlement banks for the whole banking industry. There were obvious bottleneck in the clearing system. In some cases, cheques for clearing their beneficiaries upon as their due dates into their beneficiaries account. During the period also, there was dominance of the three (3) big banks (First Bank, Union Bank and United Bank for Africa UBA). These three banks now dictated the financial direction for the rest of other so called new generation banks. Worse still, earlier deregulation of the banking industry further increased the number of banks to over 100 .

Additional new entrants had weak capitalization and also poor management quality, thus weak regulatory supervision led to the collapse of some reasonable number of the new banks in the industry shake up. According to Peterside (2004) during his research on "Critical Role of the Banking Industry in implementing the structural Adjustment programme (SAP) in Nigeria indicated that, at its peak, there were over 120 banks in the early mid 1990s as opposed to less than 20 in 1980 . The bank branches also grew rapidly, albeit within urban areas and there was a rising level of foreign participation and systematic global integration of the Nigerian banking industry; almost ten banks did not meet the regulatory requirement for funding agriculture, manufacturing and other productive sector (ie the ratio of their loans and advances that must be channeled to real sectors. The emphasis for most of them was to 
finance so called short-term deals with fast turnover, going as far as importing fast moving consumer goods thereby exerting undue pressure on the foreign exchange market. Many of the banks were quite aggressive in chasing and attracting customers as opposed to the armchair banking style of the bigger holder banks. With time, some banks took that aggression very far by recruiting pretty female bankers to go after affluent and institutional customers prostitution was legalized in the industry so to speak; the newer banks were more likely to be financially unstable because of low capital base, others depending on a single or few public sector deposits for sustenance (Peterson 2004).

\section{Research Methodology}

According to Onwumere (2005), a research design is a kind of blueprint that guides the researcher in his or her investigation and analyses. The research design that will be adopted for this research is the ex-post facto research design. The intention for the adoption of this research design hinges on two reasons. Ex-post facto research design as described by Kerlinger (1970), the ex-post facto research design also called causal comparative research is used when the researcher intends to determine cause-effect relationship between the independent and dependent variables with a view to establishing a causal link between them; the study is an impact study thus the adoption of the ex-post facto research design.

\section{Nature and Sources of Data}

The nature of data for this research will be of secondary nature. Secondary data are data which have been processed, collated and existed in published form (Onwumere, 2005). The' secondary data sources that will be used in this study will be extracted from the financial statement of Standard Trust Bank PLC and UBA before the Merger and UBA/Standard Trust Bank after the merger. The relevant data include; Profit after Tax (PAT), Total Net Assets (TNA), Loans and Advances (LA) and Bank Share Capital (BSC) for the period under study.

Population and Sample Size/Techniques : The idea of sampling or determining sample size is to obtain a part of the population from which some information about the entire population can be inferred. In line with the nature of this type of research, the population of the study is all the banks that participated in the CBN enforced Mergers and Acquisition in 2005. However our main focus is the UBA/Standard Trust Bank PLC merger, this constitutes the total sample size for this research. Therefore the sampling Techniques is the Non Probability Convenience sampling method, this was necessary because of the convenience of generating data for our case study.

Description of Research Variables:The variables for the study will be made of dependent and independent variables. Below is a breakdown of the respective variables.

\section{Independent Variable:Bank Share Capital}

Bank Share capital or issued capital or capital stock refers to the portion of a bank's equity that has been obtained (or will be obtained) by trading stock to a shareholder for cash or an equivalent item of capital value; it includes both ordinary shares and preference shares. If the market value of the shares is greater than their nominal value the shares are said to be at a premium. For this work it will be used as the independent variable since it was the variable that the banking reforms in Nigeria affected.

\section{Dependent Variables: The dependent variables include Profit after Tax, Total Net Assets and Loans and Advances}

Profitability- Profit after Tax (PAT): Profit after Tax is a measure of the profitability of a firm after accounting for all costs including tax. In accounting, net profit is equal to the gross profit minus overheads minus interest and taxes payable for a given time period.

Total Net Assets; Total Net assets sometimes referred to as net worth, is the shareholder's equity $=$ assets minus liabilities. The capital raised by the bank is used to invest in the assets of the Bank, thus in this research, we also used the Total Net Assets as proxy for growth of the bank before and after consolidation.

Loans and Advances: The term loan refers to the amount borrowed by one person from another. The amount is in the nature of loan and refers to the sum paid to the borrower. Thus, from the view point of borrower, it is 'borrowing' and from the view point of bank, it is 'lending'. 'Advance' on the other hand, is a 'credit facility' granted by the bank. Banks grant advances largely for short-term purposes, such as purchase of goods traded in and meeting other short-term trading liabilities. Loans and Advances are the banks 
source of profit, thus the bigger the share capital the more ability the bank has in granting Loans and Advances. Thus, it is also used as a proxy in this research.

\section{Models Specification}

The simple regression equation is stated thus;

$\mathrm{Y}=\mathrm{B}_{1}+\mathrm{B}_{2} \mathrm{X}_{2}+\mu$.

Where, $\mathrm{Y}$ dependent variable; $\mathrm{X}$ explanatory variable; $\mathrm{B}_{1}$ intercept of $\mathrm{Y} ; \mathrm{B}_{2}=$ slope coefficients; $\mathrm{U}=$ stochastic variables (Gujarati, 1995).

Therefore, in writing the model equation, the following proxies and symbols will be used in this research.

Bank Share Capital $=\quad$ BSC

Profit after Tax $=$ PAT

Total Net Assets $=$ TNA

Loans and Advances $\quad=\quad \mathrm{LA}$

Equation (1) will be re-written to suit the study along the four hypotheses.

Thus, for hypothesis one which states that Bank share capital do not have positive significant impact on profit after Tax before and after Consolidation, it is represented as:

$\mathrm{PAT}=\mathrm{a}+\mathrm{bBSC}+\mu$.

For hypothesis two, which states that Bank share capital does not have positive significant impact on Total Net Assets before and after Consolidation, it is represented as;

$\mathrm{TNA}=\mathrm{a}+\mathrm{bBSC}+\mu \ldots \ldots \ldots \ldots \ldots \ldots \ldots \ldots \ldots \ldots(3)$

For hypothesis three, which states that Bank share capital does not have positive significant impact on Loans and Advances before and after Consolidation, it is represented as:

$\mathrm{LA}=\mathrm{a}+\mathrm{BSC}+\mu$

\section{Technique for Analysis}

The hypotheses stated in chapter one will be tested using the Ordinary Least Square Regression model. The justification for adopting this analytical technique is based on the following premise; the ordinary least square is assumed to be the best linear unbiased estimator (Gujarati, 1995); it has minimum variance (Onwumere, 2005), and similar works in other jurisdiction adopted this technique in their study.

Test of Hypotheses : Below in a tabular form are the extract of the analyzed results from the financial statements and accounts of the DBA and STB before and after consolidation. The analyses is first and foremost done on pre-merger basis and secondly on post-merger basis.

Test of Hypothesis One Pre- Merger STB Step One: Statement of Hypothesis

Ho: Bank share capital does not have positive significant impact on profit after Tax before Consolidation.

Ha: Bank share capital has positive significant impact on profit after Tax before Consolidation.

Step Two: Presentation of SPSS model results

TABLE 4.4 Hypothesis One (STB) Descriptive Statistics (Model Summary)

\begin{tabular}{|l|l|l|l|l|l|l|}
\hline Model & R & R. Square & Adjusted R. Square & Beta & t-value & DW \\
\hline 1 & $0.937^{(a)}$ & 0.877 & 0.838 & 0.937 & 4.629 & 3.015 \\
\hline
\end{tabular}

Source: Appendix

a. Model Equation $\mathrm{PAT}=866.359+1.825 \mathrm{BSC}$

b. All requested variables entered.

Step Three: Decision Criterion

Utilizing the value under study, for STB PLC, the test table above emerged. The result reveals a positive beta value of 0.937. The positive beta shows that, there is a positive correlation between Profit after Tax and the share capital. This was agreed by $87.7 \%$ as indicated by the coefficient of determination. The $t$-value is 1.035 . From the model equation as shown above (note a, the coefficient of the equation is positive, that is the impact of. Bank Share capital on Profit after Tax is positive significant because the t-value is greater than the rule of thumb value of 2 . It was 4.629 , and it indicates significance and DW is 3.015 .

\section{Step 4: Decision}

From the foregoing, therefore, we reject the null hypothesis and accept the alternative hypothesis; thus, there is a positive significant impact of the Bank share capital on the Profit after tax of STB before consolidation. 
Test of Hypothesis Two for STB

Step one: Statement of Hypothesis

Ho: Bank share capital does not have positive significant impact on Total Net Assets before Consolidation.

Ha: Bank share capital has positive significant impact on Total Net Assets before Consolidation

Step Two: Presentation of SPSS model results

TABLE 4.5 Hypothesis Two (STB) Descriptive Statistics (Model Summary)

Source: Appendix

\begin{tabular}{|l|l|l|l|l|l|l|}
\hline Model & R & R.Square & Adjusted R, Square & Beta & t-value & DW \\
\hline 1 & $0.937^{(a)}$ & 0.878 & 0.838 & 0.937 & 4.657 & 1.382 \\
\hline
\end{tabular}

a. Model equation TNA $=-30,358.6+145.85 B S C$

b. All requested variables entered.

c. Dependent Variable: Total Net Assets

\section{Step Three: Decision criterion}

From the test table above, the result revealed a positive beta of 0.937 . The positive beta shows that there is a positive correlation between of the Banks Share Capital and the Total Net Asset of STB and also the Bank Share capital has a positive significant impact on Total Net Assets as indicated by the model summary. The coefficient of the equation is 145.852 and a t-value of 4.657 . The explained variation for the model is $87.8 \%$ as showed by the coefficient of determination while DW is 1.382 .

\section{Step Four: Decision}

With the data from above, for STB, we reject the null hypothesis and accept the alternate hypothesis which says that Bank share capital has positive significant impact on Total Net Assets before Consolidation.

Test of Hypothesis Three for STB

Step One: Statement of the hypothesis

Ho: Bank share capital does not have positive significant impact on Loans and Advances before Consolidation

Ha: Bank share capital has positive significant impact on Loans and Advances before Consolidation

Step Two: Presentation of SPSS model results

TABLE 4.6 Hypothesis Two (STB) Descriptive Statistics (Model Summary)

\begin{tabular}{|l|l|l|l|l|l|l|}
\hline Model & R & R. Square & Adjusted R. Square & Beta & t-value & DW \\
\hline 1 & $0.192^{(a)}$ & 0.037 & -0.284 & 0.192 & 0.339 & 2.110 \\
\hline
\end{tabular}

\section{Source: Appendix 5}

a Model summary LA $=20538.975+1.134$ BSC

b. All requested variables entered.

c. Dependent Variable: Loans and Advances

\section{Step Three: Decision Criterion}

From the test table above, the result revealed a positive beta of 0.192 . The positive beta shows that there is a positive correlation between of the Banks Share Capital and the Loans and Advances of STB and also the Bank Share capital has a positive non-significant impact on Loans and Advances as indicated by the $t$-value less than the rule of thumb value of 2 which indicates significance. The coefficient of the equation is 1.134 and the t-value is 0.339 . The explained variation for the model is $3.7 \%$ as showed by the coefficient of determination, which indicates that there may be other variables affecting the impact observed. DW is 2.110 .

\section{Step Four: Decision}

From the above result for STB, we reject the null hypothesis and accept the alternate hypothesis which says that Bank share capital has positive significant impact on Loans and Advances before Consolidation, though it is not significant.

Test of Hypothesis One Pre- Merger UBA

Step One: Statement of Hypothesis

Ho: Bank share capital does not have positive significant impact on profit after Tax before Consolidation.

Ha: Bank share capital has positive significant impact on profit after Tax before Consolidation. 
Step Two: Presentation of SPSS model results

TABLE 4.7 Hypothesis One (UBA) Descriptive Statistics (Model Summary)

Source: Appendix

\begin{tabular}{|l|l|l|l|l|l|l|}
\hline Model & R & R. Square & Adjusted R. Square & Beta & t-value & DW \\
\hline 1 & $0.958^{(\text {a) }}$ & 0.918 & 0.891 & 0.958 & 5.792 & 3.175 \\
\hline
\end{tabular}

a. Model Equation $\mathrm{PAT}=-3072.317+5.350 \mathrm{BSC}$

b. All requested variables entered.

\section{Step Three: Decision Criterion}

Utilizing the value under study, for UBA PLC, the test table above emerged. The result reveals a positive beta value of 0.958 . The positive beta shows that, there is a positive correlation between Profit after Tax and the share capital. This was agreed by $89.1 \%$ as indicated by the coefficient of determination. The t-value is 5.792. From the model equation as shown above (note a, the coefficient of the equation is positive, that is the impact of Bank Share capital on Profit after Tax is positive and significant because the t-value is greater than the rule of thumb value of 2 and DW is 3.175 .

\section{Step4: Decision}

From the foregoing, therefore, we reject the null hypothesis and accept the alternative hypothesis; thus, there is a positive significant impact of the Bank share capital on the Profit after tax of UBA before consolidation.

Test of Hypothesis Two for UBA

Step one: Statement of Hypothesis

Ho: Bank share capital does not have positive significant impact on Total Net Assets before Consolidation.

Ha: Bank share capital has positive significant impact on Total Net Assets before

Consolidation

TABLE 4.8 Hypothesis Two (UBA) Descriptive Statistics (Model Summary)

\begin{tabular}{|l|l|l|l|l|l|l|}
\hline Model & R & R. Square & Adjusted R. Square & Beta & t-value & DW \\
\hline 1 & $0.860^{(a)}$ & 0.740 & 0.654 & 0.860 & 2.924 & 2.228 \\
\hline
\end{tabular}

Source: Appendix

a. Model equation TNA $=131350+68.885 \mathrm{BSC}$

b. All requested variables entered.

c. Dependent Variable: Total Net Assets

\section{Step Three: Decision criterion}

From the test table above, the result revealed a positive beta of 0.860 . The positive beta shows that there is a positive correlation between the Banks Share Capital and the Total Net Asset of UBA and also the Bank Share capital has a positive significant impact on Total Net Assets as indicated by the model summary. The coefficient of the equation is 68.885 and a t-value of 2.924 . The explained variation for the model is $65.4 \%$ as showed by the coefficient of determination while DW is 2.228 .

\section{Step Four: Decision}

With the data from above, for UBA, we reject the null hypothesis and accept the alternate hypothesis which says that Bank share capital has positive significant impact on Total Net Assets before Consolidation.

\section{Test of Hypothesis Three for UBA}

Step One: Statement of the hypothesis

Ho: Bank share capital does not have positive significant impact on Loans and Advances before Consolidation

Ha: Bank share capital has positive significant impact on Loans and Advances before Consolidation

Step Two: Presentation of SPSS model results

TABLE 4.9 Hypothesis Two (UBA) Descriptive Statistics (Model Summary)

\begin{tabular}{|l|l|l|l|l|l|l|}
\hline Model & R & R. Square & Adjusted R. Square & Beta & t-value & DW \\
\hline 1 & $0.904^{(a)}$ & 0.818 & 0.757 & 0.904 & 3.672 & 2.110 \\
\hline
\end{tabular}

Source: Appendix

a Model summary LA $=-12241.5+50.912$ BSC

b. All requested variables entered. 
c. Dependent Variable: Loans and Advances

\section{Step Three: Decision Criterion}

From the test table above, the result revealed a positive beta of 0.192 . The positive beta shows that there is a positive correlation between the Banks Share Capital and the Loans and Advances of UBA and also the Bank Share capital has a positive significant impact on Loans and Advances as indicated by the $t$-value greater than the rule of thumb value of 2 which indicates significance. The coefficient of the equation is 50.912 and the $t$-value is 3.672. The explained variation for the model is $75.7 \%$ as showed by the coefficient of determination and DW is 2.110 .

\section{Step Four: Decision}

From the above result for UBA, we reject the null hypothesis and accept the alternate hypothesis which says that Bank share capital has positive significant impact on Loans and Advances before Consolidation.

\section{Test of Hypothesis One Post-Merger UBA/STB}

Step One: Statement of Hypothesis

Ho: Bank share capital does not have positive significant impact on profit after Tax after Consolidation.

Ha: Bank share capital has positive significant impact on profit after Tax after Consolidation.

\section{Step Two: Presentation of SPSS model results}

TABLE 4.10 Hypothesis One (UBA/STB) Descriptive Statistics (Model Summary)

\begin{tabular}{|l|l|l|l|l|l|l|}
\hline Model & R & R. Square & Adjusted R Square & Beta & t-value & DW \\
\hline & $0.337^{(\mathrm{a})}$ & 0.114 & -.182 & -0.337 & -0.620 & 2.159 \\
\hline
\end{tabular}

\section{Source: Appendix}

a Model Equation PAT $=27883.457-1.461 \mathrm{BSC}$

b. All requested variables entered.

\section{Step Three: Decision Criterion}

Utilizing the value under study, for post Merger UBA/STB PLC, the test table above emerged. The result reveals a negative beta value of- 0.337 . The negative beta shows that, there is a negative correlation between Profit after Tax and the share capital of the bank after consolidation. This was agreed by $18.2 \%$ as indicated by the coefficient of determination. The $t$-value is -0.620 . From the model equation as shown above (note $a$, the coefficient of the equation is negative, that is the impact of Bank Share capital on Profit after Tax is negative and non-significant because the t-value is less than the rule of thumb value of 2 and DW is 2.159 .

\section{Step 4: Decision}

From the foregoing, therefore, we accept the null hypothesis and reject the alternative hypothesis; thus, there is a negative non-significant impact of the Bank share capital on the Profit after tax of UBA/STB after consolidation.

\section{Test of Hypothesis Two for Post Merger UBA/STB}

Step one: Statement of Hypothesis

Ho: Bank share capital does not have positive significant impact on Total Net Assets after Consolidation.

Ha: Bank share capital has positive significant impact on Total Net Assets after Consolidation

Step Two: Presentation of SPSS model results

TABLE 4.11 Hypothesis Two (UBA/STB) Descriptive Statistics (Model Summary)

\begin{tabular}{|l|l|l|l|l|l|l|}
\hline Model & R & R. Square & Adjusted R. Square & Beta & t-value & DW \\
\hline 1 & $0.878^{\mathrm{W}}$ & 0.772 & 0.696 & 0.878 & 3.184 & 1.744 \\
\hline
\end{tabular}

Source: Appendix

a Model equation TNA $=731477.3+78.273 \mathrm{BSC}$

b All requested variables entered.

c. Dependent Variable: Total Net Assets

\section{Step Three: Decision criterion}

From the test table above, the result revealed a positive beta of 0.878 . The positive beta shows that there is a positive correlation between of the Banks Share Capital and the Total Net Asset of the bank after consolidation, also the Bank Share capital has a positive significant impact on Total Net Assets as indicated by the model 
summary. The coefficient of the equation is 78.273 and a t-value of 3.184. The explained variation for the model is $69.6 \%$ as showed by the coefficient of determination while DW is 1.744 .

\section{Step Four: Decision}

From the data from above, we reject the null hypothesis and accept the alternate hypothesis which says that Bank share capital has positive significant impact on Total Net Assets after Consolidation.

\section{Test of Hypothesis Three for Post Merger UBA/STB \\ Step One: Statement of the hypothesis}

Ho: Bank share capital does not have positive significant impact on Loans and Advances after Consolidation

Ha: Bank share capital has positive significant impact on Loans and Advances after Consolidation

\section{Step Two: Presentation of SPSS model results}

TABLE 4.12 Hypothesis Three (UBA/STB) Descriptive Statistics (Model Summary)

Source: Appendix

\begin{tabular}{|l|l|l|l|l|l|l|}
\hline Model & R & R. Square & Adjusted R. Square & Beta & t-value & DW \\
\hline 1 & $0.950^{(a)}$ & 0.903 & 0.871 & 0.950 & 5.298 & 2.336 \\
\hline
\end{tabular}

a Model summary LA $=-14977+50.767$ BSC

b. All requested variables entered.

c. Dependent Variable: Loans and Advances

Step Three: Decision Criterion: From the test table above, the result revealed a positive beta of 0.950 . The positive beta shows that there is a positive correlation between of the Banks Share Capital and the Loans and Advances of post merger UBA/STB and also the Bank Share capital has a positive significant impact on Loans and Advances as indicated by the t-value greater than the rule of thumb value of 2 which indicates significance. The coefficient of the equation is 50.767 and the t-value is 5.298. The explained variation for the model is $87.1 \%$ as showed by the coefficient of determination and DW is 2.336 .

\section{Step Four: Decision}

From the above post Merger result for UBA/STB, we reject the null hypothesis and accept the alternate hypothesis which says that Bank share capital has positive significant impact on banks Loans and Advances after Consolidation.

\section{Summary Of Findings, Conclusions And Recommendations}

SUMMARY OF FINDINGS: From the result obtained from the hypotheses tested the following findings was revealed;

1. There was a positive significant impact of Bank share capital on the Profit after tax of STB before consolidation as t-value and coefficient of Bank Share capital was 4.629 and 1.825 respectively.

2 Bank share capital had a positive significant impact on Total Net Assets before Consolidation for STB, the t-value was 4.656 and the coefficient of the independent variable (Bank Share Capital) was 145.85.

3. Bank share capital had a positive non-significant impact on Loans and Advances before Consolidation for STB, the t-value was 0.339 and the coefficient of Bank Share Capital was 1.134.

4. There was a positive significant impact of Bank share capital on the Profit after tax of DBA before consolidation. The t-value and coefficient of Bank Share Capital was 5.792 and 5.350 respectively.

5. Bank share capital had a positive significant impact on Total Net Assets before Consolidation for UBA as the tvalue was 2.942 and coefficient of Bank Share Capital was 68.885 .

6 Bank share capital had a positive significant impact on Loans and Advances before Consolidation for UBA as the t-value and coefficient of Bank Share Capita was 3.672 and 50.912 respectively.

7. There was a negative non-significant impact of the Bank share capital on the Profit after tax of UBA/STB after consolidation, the $t$-value and coefficient of Bank Share Capita was -0.620 and -1.461 respectively.

8. Bank share capital had a positive significant impact on Total Net Assets after Consolidation for post merger UBA/STB indicated by a t-value of 3.184 and the Bank Share Capital was 78.273 and

9. Post Merger result for UBA/STB indicates that the Bank share capital had a positive significant impact on banks Loans and Advances after Consolidation as the t-value and coefficient of Bank Share Capital was 5.298 and 50.767.

CONCLUSIONS: Banks consolidation through mergers and acquisitions and the N25bn recapitalization exercise, the thirteenth and first items on Professor Charles Soludo's 13-point reform agenda in the banking industry, came to 
an end precisely on $31^{\text {st }}$ December, 2005 as promised. Hear him, "Consolidation of banking institutions through mergers and acquisitions. Banks that do not meet the minimum paid up capital by end of December 2005 or which remains un-sound/marginal would be liquidated by January 2006.

The vision of Professor Soludo was a banking system that is part of the global change, and which is strong, competitive and reliable. It is a banking system which depositors can trust, and investors can rely upon. He gave reasons such as persistent Illiquidity, weak corporate governance, poor assets quality, insider abuses, weak capital base, unprofitable operations, and over-dependency on public sector funds, among others, that necessitated the banking sector reform. One of the recent developments in the banking system before the consolidation, which was of great concern to the monetary authorities was the significant dependence of many Nigerian banks on government deposits, with the three tiers of government and parastatals accounting for over 20 percent of total deposit liabilities of deposit money banks. Although the distribution among banks was not uniform, there are some banks whose dependency ratios were in excess of 50 percent. The implications are that the resources base of such banks is weak and volatile, rendering their operations highly vulnerable to swings in government revenue, arising from the uncertainties of the international oil market. Thus the justification for the banking was that many banks appeared to have abandoned their essential intermediation role of mobilizing savings and inculcating banking habit at the household and micro enterprise levels. The apathy of banks towards small savers, particularly at the grass root level not only compounded the problems of low domestic savings and high bank lending rates in the country, also reduced access to relatively cheap and stable funds that could provide a reliable source of credit to the productive sectors at affordable rates of interest. In addition, savings mobilization at the grass root level has been discouraged by the unrealistic requirements, by many banks, for opening accounts with them. The banks were expected to shore up their capital through the injection of fresh funds where applicable, but were most importantly encouraged to enter into merger/acquisition arrangements with other relatively smaller banks thus taking the advantage of economies of scale to reduce cost of doing business and enhance competitiveness locally and internationally.

However as could be observed from the findings of this research using empirical figures from the financial statements of STB and DBA pre and post merger, it was observed that the intended reforms of increasing the share capital of bank did not have any impact on the bank performance indicator. Before the consolidation, the share capital of both STB and UBA was found to be positive and significant on their profit after tax, total net assets and loans and advances granted by the bank. However, it was found to be insignificant on loans and advances of STB before the consolidation exercise. From results obtained after consolidation, it shows that the impact of the reform on the profitability of the bank was negative and non significant, which indicates the reform did not help to increase the profitability of the Bank as was intended by the reform, however, the result shows that, it had an impact on the assets and loans and advances granted by the bank after consolidation. This supported the views of Soludo, that the increased share capital will make Nigerian Banks stronger and enable them to grant more loans and advances to investors thus fulfilling the traditional role of banks in mobilizing saving from the surplus earners and lending to the deficit earners.

Recommendations: There is no doubt the banking sector before $31^{\text {st }}$ December, 2004 was begging for reform. All the reasons given by the regulatory authorities for the reforms were relevant and evident. However with the benefit of hindsight, which, as they say, is $20 / 20$, it is clearly evident that CBN did not adequately prepare itself for the enormous task it set for itself. Much as it deserves credit for not extending the deadline, which took most of the fourteen banks that did not make it by surprise, there are traces of inadequate preparation, poor enlightenment campaign, as well as haphazard blueprint to drive the exercise. As could be observed from the findings of this research, the following recommendation is made:

Firstly, for the recapitalized banks to avoid going back to the "distress syndrome" era as was recently seen in problems of Oceanic Bank, Intercontinental Bank, AfriBank, Bank PHB and Union Bank the CBN has the enormous responsibility of ensuring that the banks are supervised effectively and all loop-holes blocked to avoid abuse. The regulatory authority must re-engineer its supervision department and man it with qualified and experienced personnel to carry out this assignment in a professional manner. The automation of the process for the rendition of returns by banks and other financial institutions through the enhanced Financial Analysis Surveillance System (e-FASS) must be driven and implemented with all sense of purpose. In addition, the recommendations contained in the Pius Okigbo panel report on the Reorganization and Reform of Central Bank of Nigeria of 1994 need to be revisited and implemented to give a further impetus to the performance of the regulatory authority that is it must direct the search light on itself too.

Secondly, The CBN must also drive the full implementation of the "Code of Corporate Governance for Banks in Nigeria Post Consolidation" dated January 5, 2006. Implementing this code to the letter alone will sanitize and re-position our banks; restore international confidence and that of the depositors. All banks must be Treated equally without favour or sentiment. It is important for the banks to be separated from their CEO's and shareholders. Experience has shown that those banks whose CEO's are closer to the 
government in power gain undue advantage over others. This should not be the case, otherwise before we start reaping the dividends of the reforms the whole exercise will come to naught. The CBN must keep its professional distance with the commercial banks.

Thirdly, The CBN must, as a matter of urgency, decide finally on the issue of recapitalization expenses and bad debt as allowing these two heavy burdens with the banks will distract their attention to make the desired progress. The CBN should not join issues with the owners of the liquidated banks that dragged it to court but should fast track the exercise in the interest of many depositors whose lives hinge on these savings. Already some banks created "ghost depositors" to inflate their customer base to benefit from pay-off by the NDIC. The banks must not be allowed to get away with this fraud at the expense of the taxpayers. This was indicated by the negative impact observed from the findings of this research, as the reforms did not have any impact on the profitability of the bank.

Lastly, emphasis should not be place on forced regulatory increased in share capital, instead effort should be made by the regulatory authorities to encourage bank to raise their capital base without interferences from the authorities. The spirit of competition will bring out the best in the banks and the apex bank should not hesitate to excise any bank confirmed to be weak given all the liquidity indicators before it affects other banks. Of course, in doing this the interest of the shareholders, depositors, and the employees will be taken into consideration, among other things.

\section{References}

[1]. Adam, J. A. (2005) "Banking Sector Reforms: The Policy Challenges of Bank Consolidation in Nigeria." A Paper Presented at the 46th Nigerian Economic Society (NES) Annual Conference, Lagos. 23rd - 25th August

[2]. Afolabi J.A. (2004), "Implications of the Consolidation of banks for the Nigerian banking System" Paper presented at the NDIC organized Workshop for FICAN Enugu

[3]. Akhavein, J.D., A.N. Berger and D.B. Humphrey (1997), "The Effects of Megamergers on Efficiency and Prices: Evidence from a Bank Profit Function" Review of Industrial Organization, 12, 95-139

[4]. Akingbola E. (2006), "Change Management and Capacity Building Leadership Conference on Nigerian Banking Reform" A paper delivered at the $20^{\text {th }}$ Banker meeting in London

[5]. Berger, A.N., and G.F. Udell (1998), "The economics of small business finance: The roles of private equity and debt markets in the financial growth cycle" Journal of Banking \& Finance, 22, 613-673

[6]. Chamberlain, D. (1992) The Effects of Bank Ownership changes on subsidiary level earnings. Unpublished; The Wharton School, University of Pennsylvania

[7]. Crockett B. (1995), "First Bank Claims Wells Overstated Deal Savings American Banker Custom, and Cultural Change as Informational Cascades" Journal of Political Economy, 100 (5), 992-1026

[8]. Cybo-Ottone, A., and M. Murgia (2000), "Mergers and shareholder wealth in European banking" Journal of Banking and Finance, 24, 831-859

[9]. Davies. L, (2006) "Prosperity without losers" The progress Report P: 1-5

[10]. DeYoung R. (1993) "Determinants of Cost Efficiency in bank Mergers" $\quad$ Working Paper $\quad 93-1 \quad$ Office of the Comptroller of Currency earnings. Unpublished; The Wharton School, University of Pennsylvania

[11]. Fukuyama, H. (1993) "Technical and Scale Efficiency in Japanese Commercial Banks: A non-Parametric Approach" Applied Economics 25, 1101-12

[12]. Gujarati, D.N. (1995), Basic Econometrics, Singapore: Mcgraw- Hill Book CoHall, M. J. B. (1999) "Japan's Big Bang: The Likely Winners and Losers" Journal of International Banking Law 7, 204-16 [13]. Hannan T.H and J.D Walken (1989) "Returns to Bidders and Targets in the
from the Banking Industry" Journal of Financial Services Research, 3, Pp5-16

[14]. Houston J.H and M. Ryngeart (1994), "The overall gains from large bank mergers" Journal of banking and finance, 18, 6 pp 11551176

[15]. Kerlinger, F.N. (1973), Foundations of Behavioural Research Techniques in Business and Economics Eleventh Edition, Boston; McGraw Hill Irwin

[16]. Kwan, S. (2004). "Banking Consolidation" Federal Reserve Bank of San Francisco (FRBSF) Economic Letter, June 18

[17]. Lemo, T. (2005) "Regulatory Oversight and Stakeholder Protection" A Paper Presented at the BGL Mergers and Acquisitions Interactive Seminar, held at Eko Hotels \& Suits. V. I., on June 24

[18]. Madura J. and KJ Wiant (1994), "Long Term Valuation Effects of Bank Acquisitions" Journal of Banking and Finance, Vol. 18, 1135-1154

[19]. McKillop, D. G., Glass, J. C. and Morikawa, Y. (1996) “The Composite CostFunction and Efficiency in Giant Japanese Banks" Journal of Banking and Finance 20, 1651-71

[20]. Nnanna, O. J. (2004), "Beyond Bank Consolidation: The Impact of Society" A Paper Presented at the 4th Annual Monetary Policy Conference of the Central Bank of Nigeria, Abuja, 18th - 19th November

[21]. Oladepo, E.D. (2010), "Mergers \& Acquisitions and Efficiency of Financial Intermediation Nigeria Banks: An Empirical Analysis” International Journal of Business and Management Vol. 5, No. 5

[22]. Onwumere, J.U.J (2005), Business and Economic Research Method, Lagos; Don-Vinton Limited

[23]. Pautler P.A. (2001), "Evidence on Mergers and Acquisitions" Bureau of Economics Federal Trade Commission Working Paper

[24]. Piloff, S.J. (1996) "Performance changes and shareholder wealth creation associated with mergers of publicly traded institutions" Journal of Money banking and Finance, 28, pp.294-310

[25]. Rhoades, S,A. (1990), "A Summary of Merger Performance Studies in Banking, 1980- 1993, and an Assessment of the "Operating Performance" and "Event Study, 167, Washington, DC: Board of Governors of the Federal Reserve System.

[26]. Rhoades, S.A. (1993), "The efficiency effects of bank mergers: and overview of case studies of nine mergers" OCDE

[27]. Rostral consulting (2005) Restral E letter: Current Reforms in Nigerian Banking www. Restral. Com. 
[28]. Sanusi. L. S. (2010) "The Nigerian Banking industry: what went wrong and the way for 2-8

[29]. Schenk, H. (2000), Policy Implications of Purely Strategic Mergers, London: "Mixed Reaction on Banks consolidation" The Nigerian ward, The Nigeria Banker, vol 12, no 1, pp

Prentice-Hall Soludo., C.C (2004)

\section{APPENDIX1}

REGRESSION RESULT FOR HYPOTHESIS ONE OF STANDARD TRUST PLC PRE-MERGER Descriptive Statistics

\begin{tabular}{|l|r|r|r|}
\hline & Mean & Std. Deviation & N \\
\hline PAT & 2358.60 & & 303.222 \\
\hline BSC & 817.60 & 155.598 & 5 \\
\hline
\end{tabular}

Correlations

\begin{tabular}{|c|c|c|c|}
\hline & & PAT & BSC \\
\hline Pearson Correlation & PAT & 1.000 & ,937 \\
\hline & BSC & .937 & 1.000 \\
\hline \multirow[t]{2}{*}{ Sig. (1 -tailed) } & PAT & & .009 \\
\hline & $\mathrm{BSC}$ & .009 & \\
\hline \multirow[t]{2}{*}{$\mathrm{N}$} & PAT & 5 & 5 \\
\hline & BSC & 5 & 5 \\
\hline
\end{tabular}

Model Summary

\begin{tabular}{|l|l|l|l|l|l|l|}
\hline Model & R & R2 & Adjusted R2 & $\begin{array}{l}\text { Std error of the } \\
\text { estimate }\end{array}$ & F change & D.W \\
\hline 1 & $.937 \mathrm{a}$ & .877 & .836 & 122.709 & 21.125 & 3.015 \\
\hline
\end{tabular}

a Predictors: (Constant), BSC

b Dependent Variable: PAT

ANOVA(b)

\begin{tabular}{|l|r|r|r|r|r|}
\hline Model & Sum of Squares & df & Mean Square & F & Sig. \\
\hline gression Residual & 322600.79945172 .401 & & 322600.79915057 .467 & 21.425 & \\
Total & 367773.200 & & 3 & & $.019(\mathrm{a})$ \\
& & 4 & & & \\
\hline
\end{tabular}

a Predictors: (Constant), BSC

b Dependent Variable; PAT

Coefficients(a)

\begin{tabular}{|c|c|c|c|c|c|}
\hline Model & Unstandardized C & oefficients & Standardized Coefficients & $\mathrm{t}$ & Sig. \\
\hline & B & Std, Error & Beta & & \\
\hline \begin{tabular}{|l}
1 \\
BSC \\
\end{tabular} & 866.3591 .825 & $\begin{array}{r}327.028 \\
.394 \\
\end{array}$ & .937 & 2.6494 .629 & $\begin{array}{l}.077 \\
.019 \\
\end{array}$ \\
\hline
\end{tabular}

a Dependent Variable: PAT

REGRESSION RESULT FOR HYPOTHESIS TWO OF STANDARD TRUST PLC PRE-MERGER Descriptive Statistics

\begin{tabular}{|r|r|r|r|}
\hline & Mean & Std. Deviation & N \\
\hline TNABSC & 88872.20 & 24183.748 & 5 \\
\hline & 817.60 & 155.598 & 5 \\
\hline
\end{tabular}

\section{Correlations}

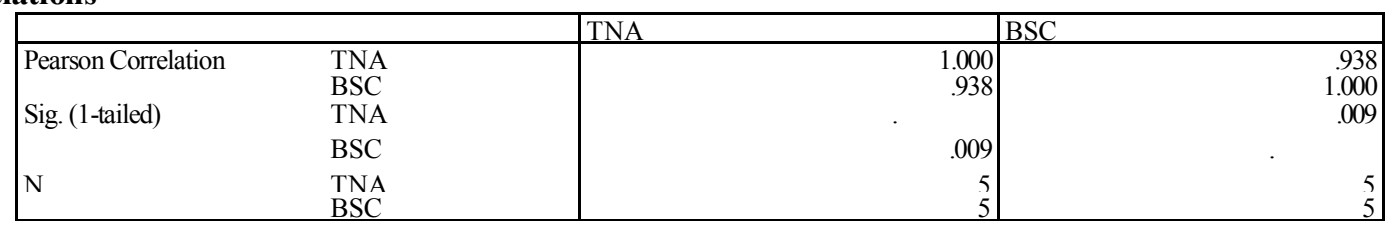

\section{Model Summary}

\begin{tabular}{|l|l|l|l|l|l|l|}
\hline Model & R & R2 & Adjusted R2 & $\begin{array}{l}\text { Std error of the } \\
\text { estimate }\end{array}$ & F change & D.W \\
\hline 1 & $938 \mathrm{a}$ & .879 & .839 & 9710.135 & 21.812 & 1.382 \\
\hline
\end{tabular}

a Predictors: (Constant), BSC

b Dependent Variable: TNA 
ANOVA(b)

\begin{tabular}{|ll|r|r|r|r|r|}
\hline Model & Sum of Squares & df & Mean Square & F & Sig. \\
\hline 1 & Regression & 2056554478.947 & 1 & 2056554478.947 & 21.812 & $.019(\mathrm{a})$ \\
& Residual & 282860193.853 & 3 & 94286731.284 & & \\
& Total & 2339414672.800 & 4 & & \\
\hline
\end{tabular}

a Predictors: (Constant), BSC b Dependent Variable: TNA

Coefficients(a)

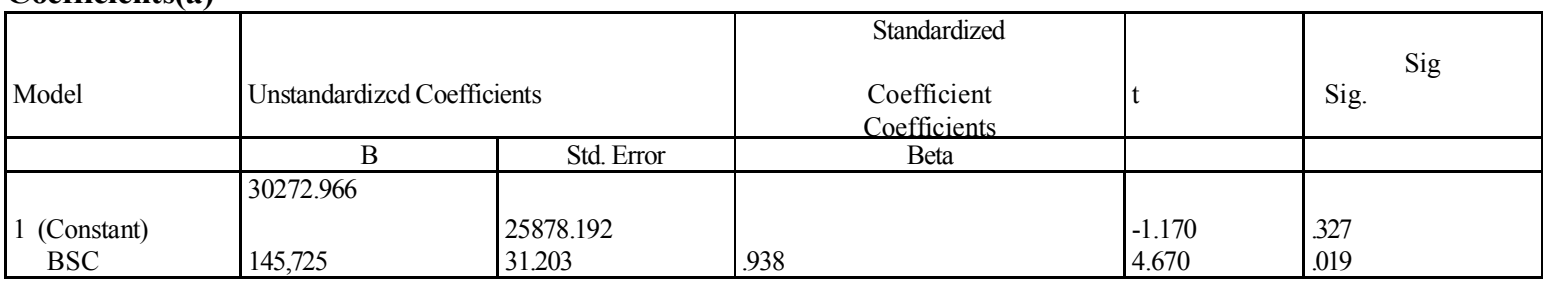

a Dependent Variable: TNA

REGRESSION RESULT FOR HYPOTHESIS THREE OF STANDARD TRUST PLC PRE-MERGER Descriptive Statistics

\begin{tabular}{|l|r|r|l|}
\hline & Mean & Std. Deviation & N \\
\hline LA & 21466.40 & 917.708 & 5 \\
\hline BSC & 817.60 & 155.598 & 5 \\
\hline
\end{tabular}

\section{Correlations}

\begin{tabular}{|ll|r|r|}
\hline & & TNA & BSC \\
\hline Pearson Correlation & LA & 1.000 & .192 \\
Sig. (1-tailed) & BSC & .192 & 1.000 \\
$\mathrm{~N}$ & LA &. & .378 \\
& BSC & .009 & 5 \\
& LA & 5 & 5 \\
\hline
\end{tabular}

\section{Model Summary}

\begin{tabular}{|l|l|l|l|l|l|l|}
\hline Model & $\begin{array}{l}\text { R } \\
\text { Rnnma }\end{array}$ & R2 & $\begin{array}{l}\text { Adjusted R2 } \\
\text { E }\end{array}$ & $\begin{array}{l}\text { Std error of } \\
\text { The estimate }\end{array}$ & F change & D.W \\
\hline 1 & $.192 \mathrm{a}$ & .037 & $\begin{array}{l}-.284 \\
115\end{array}$ & 1039.895 & .115 & 2.110 \\
\hline
\end{tabular}

a Predictors: (Constant), BSC

b Dependent Variable: LA

ANOVA(b)

\begin{tabular}{|l|c|lr|l|l|l|}
\hline Model & Sum of Squares & df & Mean & Square & F & Sig, \\
\hline 1 Regression & 124607.799 & 1 & 124607.79 & & .115 & $.757(\mathrm{a})$ \\
Residual & 3244147.401 & 3 & 1081382.467 & & \\
Total & 3368755.200 & 4 & & & & \\
\hline
\end{tabular}

a Predictors: (Constant), BSC

b Dependent Variable: LA

Coefficients(a)

\begin{tabular}{|ll|l|l|l|l|l|}
\hline Model & \multicolumn{2}{|l|}{$\begin{array}{l}\text { Unstandardized Coefficients } \\
\text { roefficiontc }\end{array}$} & Standardized & $\mathrm{t}$ & Sig. \\
\hline & $\mathrm{B}$ & Std. Error & Beta & & \\
& & 20538.975 & 2771.394 & & 7.411 & .005 \\
\hline 1 & (Constant) & BSC & 1.134 & 3.342 & .339 & .757 \\
\hline
\end{tabular}

a Dependent Variable: LA 


\section{APPENDIX 2}

REGRESSION RESULT FOR HYPOTHESIS ONE OF UBA PLC PRE-MERGER Descriptive Statistics

\begin{tabular}{|l|r|r|r|}
\hline & Mean & Std. Deviation & N \\
\hline PAT & 3112.20 & & 1664.635 \\
\hline BSC & 1147.00 & 310.093 & 5 \\
\hline
\end{tabular}

\section{Correlations}

\begin{tabular}{|c|c|c|c|}
\hline & & PAT & $\mathrm{BSC}$ \\
\hline \multirow[t]{2}{*}{ Pearson Correlation } & PAT & 1.000 & .961 \\
\hline & $\mathrm{BSC}$ & .961 & 1.000 \\
\hline \multirow[t]{2}{*}{ Sig. (1 -tailed) } & PAT & & .005 \\
\hline & $\mathrm{BSC}$ & .005 & \\
\hline \multirow[t]{2}{*}{$\mathrm{N}$} & PAT & 5 & 5 \\
\hline & $\mathrm{BSC}$ & 5 & 5 \\
\hline
\end{tabular}

\section{Model Summary}

\begin{tabular}{|l|l|l|l|l|l|l|}
\hline Model & R & R2 & Adjusted R2 & $\begin{array}{l}\text { Std error of the } \\
\text { estimate }\end{array}$ & F change & D.W \\
\hline 1 & $.916 \mathrm{a}$ & .924 & .899 & 530.130 & 36.440 & 2.110 \\
\hline
\end{tabular}

a Predictors: (Constant), BSC

b Dependent Variable: PAT

\begin{tabular}{|c|c|c|c|c|c|}
\hline Model & Sum of Squares & df & Mean Square & $\mathrm{F}$ & Sig. \\
\hline $\begin{array}{l}\text { Regression Residual } \\
\text { Total }\end{array}$ & $\begin{array}{r}10240924.032 \\
8433114.768 \\
11084038.800\end{array}$ & $\begin{array}{l}1 \\
3 \\
4\end{array}$ & $\begin{array}{r}10240924.032 \\
281038.256\end{array}$ & 36.440 & $.0009(a)$ \\
\hline
\end{tabular}

a Predictors: (Constant), BSC

b Dependent Variable; PAT

\section{Coefficients(a)}

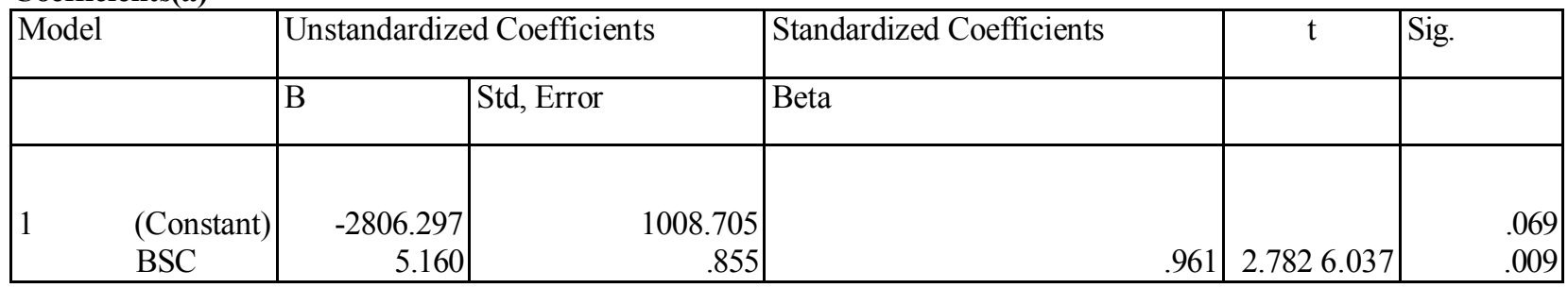

a Dependent Variable: PAT

\section{REGRESSION RESULT FOR HYPOTHESIS TWO OF UBA PLC PRE-MERGER Descriptive Statistics}

\begin{tabular}{|l|l|l|l|}
\hline & Mean & Std. Deviation & N \\
\hline TNA & 210981.20 & 23868.452 & 5 \\
BSC & 1147.00 & 310.093 & 5 \\
& & & \\
\hline
\end{tabular}

\section{Correlations}

\begin{tabular}{|ll|l|l|}
\hline & TNA & BSC \\
\hline Pearson Correlation & TNA & 1.000 & .862 \\
\hline
\end{tabular}




\begin{tabular}{|ll|r|r|} 
& BSC & .862 & 1.000 \\
Sig. (1-tailed) & TNA &. & .030 \\
& BSC & .030 &. \\
& TNA & 5 & 5 \\
& BSC & 5 & 5 \\
\hline
\end{tabular}

Model Summary

\begin{tabular}{|l|l|l|l|l|l|l|}
\hline Model & R & R2 & Adjusted R2 & $\begin{array}{l}\text { Std error of the } \\
\text { estimate }\end{array}$ & F change & D.W \\
\hline 1 & $.862 \mathrm{a}$ & .743 & .657 & 13972.200 & 8.673 & 2.099 \\
\hline
\end{tabular}

a Predictors: (Constant), BSC ] b Dependent Variable: TNA

ANOVA(b)
\begin{tabular}{|l|l|l|l|l|l|}
\hline Model & Sum of Squares & df & Mean Square & F & Sig. \\
\hline $1 \quad$ Regression & 1693144880.066 & 1 & 1693144880.066 & 8.673 & $.060(\mathrm{a})$ \\
Residual & 585667098.734 & 3 & 195222366.245 & & \\
Total & 2278811978.800 & 4 & & & \\
\hline
\end{tabular}

a Predictors: (Constant), BSC b Dependent Variable: TNA

Coefficients(a)

\begin{tabular}{|c|c|c|c|c|c|}
\hline Model & Unstandardiz & Coefficients & Standardized Coefficients & $\mathrm{t}$ & Sig. \\
\hline & B & Std. Error & Beta & & \\
\hline \begin{tabular}{|ll}
1 & (Constant)
\end{tabular} & 134880.456 & 26585.588 & & 5.073 & .015 \\
\hline $\mathrm{BSC}$ & 66.348 & 22.529 & .862 & 2.945 & .060 \\
\hline
\end{tabular}

a Dependent Variable: TNA

REGRESSION RESULT FOR HYPOTHESIS THREE OF UBA PLC PRE-MERGER Descriptive

Statistics

\begin{tabular}{|l|r|r|r|}
\hline & Mean & Std. Deviation & N \\
\hline LA & 46612.60 & 16780.893 & 5 \\
BSC & 1147.00 & 310.093 & 5 \\
\hline
\end{tabular}

\section{Correlations}

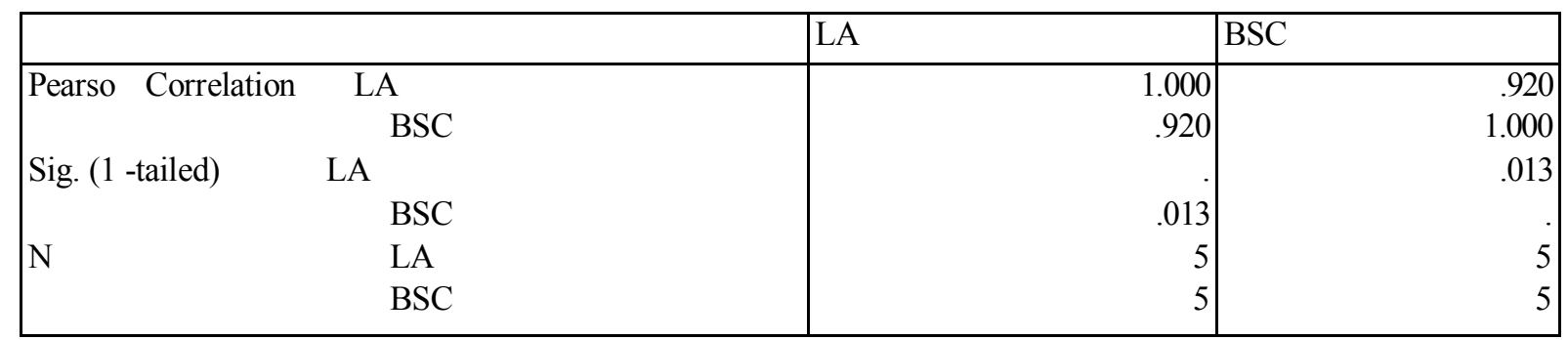

\section{Model Summary}

\begin{tabular}{|l|l|l|l|l|l|l|}
\hline Model & R & R2 & Adjusted R2 & $\begin{array}{l}\text { Std error of the } \\
\text { estimate }\end{array}$ & F change & D.W \\
\hline 1 & $.920 \mathrm{a}$ & .847 & .796 & 7580.930 & 16.600 & 3.209 \\
\hline
\end{tabular}

a Predictors: (Constant), BSC

b Dependent Variable: LA

ANOVA(b)

\begin{tabular}{|l|l|l|l|l|}
\hline Model & Sum of Squares & df $\quad$ Mean Square $\quad F \quad$ & Sig. \\
\hline
\end{tabular}

www.iosrjournals.org $\quad 74 \mid$ Page 
The Impact of Banking Reforms on the Profitability of Nigerian Banking Industry

\begin{tabular}{|l|l|l|l|l|l|}
\hline gression & 953981949.056 & 1 & 953981949.056 & 16.600 & $.027(\mathrm{a})$ \\
Residual & 172411490.144 & 3 & 57470496.715 & & \\
Total & 1126393439.200 & 4 & & & \\
& & & & & \\
\hline
\end{tabular}

a Predictors: (Constant), BSC

b Dependent Variable: LA

Coefficients(a)

\begin{tabular}{|c|c|c|c|c|c|}
\hline \multirow[t]{2}{*}{ Model } & \multicolumn{2}{|c|}{ Unstandardized Coefficients } & \multirow{2}{*}{\begin{tabular}{|c|} 
Standardized Coefficients \\
Beta
\end{tabular}} & \multirow[t]{2}{*}{$\mathrm{t}$} & \multirow[t]{2}{*}{ Sig. } \\
\hline & $\mathrm{B}$ & Std. Error & & & \\
\hline (Constant) & 10510.520 & 14424.606 & & -.729 & .519 \\
\hline $\mathrm{BSC}$ & 49.802 & 12.224 & & \begin{tabular}{|l|l|}
.920 & 4.074 \\
\end{tabular} & .027 \\
\hline
\end{tabular}

a Dependent Variable: LA

\section{APPENDIX 3}

REGRESSION RESULT FOR HYPOTHESIS ONE OF UBA/STB PLC POST-MERGER Descriptive Statistics

\begin{tabular}{|r|r|r|r|}
\hline & Mean & Std. Deviation & N \\
\hline & & & \\
3771.24 & 16365.474 & & \\
& 8320.40 & & 5 \\
\hline
\end{tabular}

\section{Correlations}

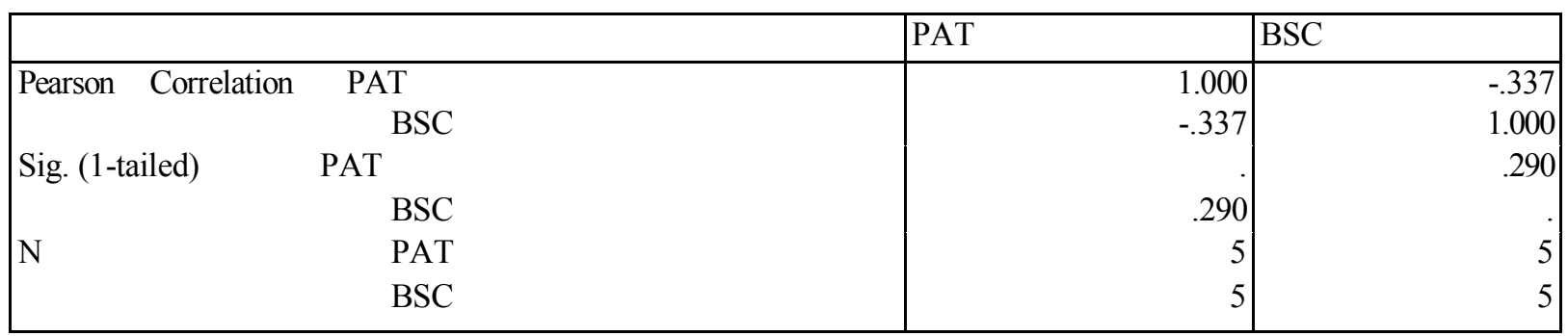

Model Summary

\begin{tabular}{|l|l|l|l|l|l|l|}
\hline Model & R & R2 & Adjusted R2 & $\begin{array}{l}\text { Std error of the } \\
\text { estimate }\end{array}$ & F change & D.W \\
\hline 1 & $.337 \mathrm{a}$ & .113 & -.182 & 17793.576 & .384 & 2.159 \\
\hline
\end{tabular}

a Predictors: (Constant), BSC

b Dependent Variable: PAT

ANOVA(b)

\begin{tabular}{|c|cc|l|l|l|l|}
\hline Model & Sum of Squares & df & Mean Square & F & Sig. \\
\hline $\begin{array}{c}\text { gression Residual } \\
\text { Total }\end{array}$ & 121480869.488 & 949834033.312 & 1 & 121480869.488 & .384 & $.579(\mathrm{a})$ \\
& 1071314902.800 & & 3 & 316611344.437 & & \\
\hline
\end{tabular}

a Predictors: (Constant), BSC

b Dependent Variable: PAT Coefficients (a)

\begin{tabular}{|c|c|c|c|c|c|c|}
\hline Model & Unstandardized & Coefficients & Standardized Coefficients & & $\mathrm{t}$ & Sig. \\
\hline & B & Std. Error & Beta & & & B \\
\hline $\begin{array}{ll}1 & \text { (Constant) } \\
\text { BSC } & \\
\end{array}$ & $\begin{array}{r}27880.405 \\
-1.461\end{array}$ & $\begin{array}{r}21180.434 \\
2.359\end{array}$ & & -.337 & $\begin{array}{r}1.316- \\
.619\end{array}$ & $\begin{array}{l}.280 \\
.579 \\
\end{array}$ \\
\hline
\end{tabular}


a Dependent Variable: PAT

Descriptive Statistics

\begin{tabular}{|c|c|c|c|}
\hline . & Mean & Std. Deviation & $\mathrm{N}$ \\
\hline TNA & 1048565.80 & 655161.297 & 5 \\
\hline $\mathrm{BSC}$ & 8320.40 & .3771 .242 & 5 \\
\hline
\end{tabular}

Correlations

\begin{tabular}{|c|c|c|c|}
\hline & & TNA & $\overline{\mathrm{BSC}}$ \\
\hline Pearson Correlation & TNA & 1.000 & .400 \\
\hline & BSC & .400 & 1.000 \\
\hline Sig. (1-tailed) & TNA & . & .252 \\
\hline & BSC & .252 & . \\
\hline $\mathrm{N}$ & TNA & 5 & 5 \\
\hline & $\mathrm{BSC}$ & 5 & 5 \\
\hline
\end{tabular}

Model Summary

\begin{tabular}{|l|l|l|l|l|l|l|}
\hline Model & R & R2 & Adjusted R2 & $\begin{array}{l}\text { Std error of } \\
\text { thatimata }\end{array}$ & F change & D.W \\
\hline 1 & $.400 \mathrm{a}$ & .160 & -.120 & 693346.051 & .572 & 2.711 \\
\hline
\end{tabular}

u Predictors: (Constant), BSC b Dependent Variable: TNA

ANOVA(b)

\begin{tabular}{|l|l|r|l|l|l|}
\hline Model & Sum of Squares & df & Mean Square & F & Sig. \\
\hline $1 \quad$ Regression & 274759056935.086 & 1 & 274759056935.086 & .572 & $.505(\mathrm{a})$ \\
Residual & 1442186241255.715 & 3 & 480728747085.238 & & \\
Total & 1716945298190.800 & 4 & & & \\
\hline
\end{tabular}

a Predictors: (Constant), BSC

b Dependent Variable: TNA

Coefficients(a)

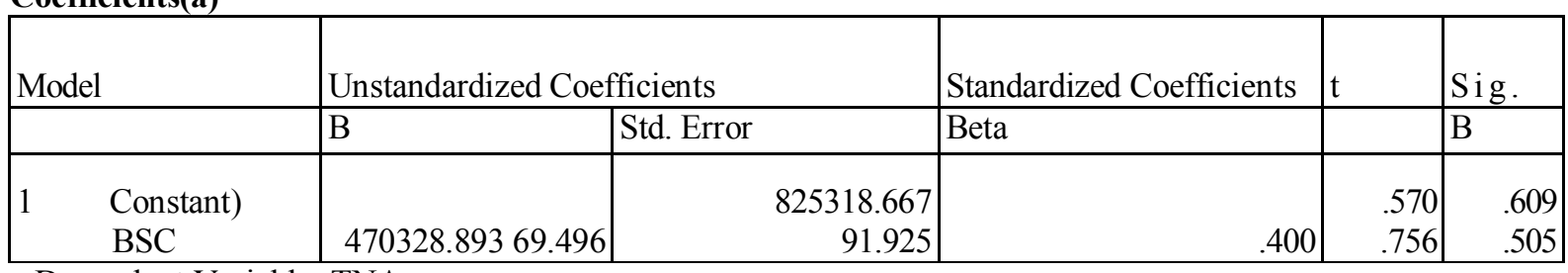

a Dependent Variable: TNA

REGRESSION RESULT FOR HYPOTHESIS THREE OF UBA/STB PLC POST-MERGER Descriptive Statistics

\begin{tabular}{|c|c|c|c|c|}
\hline & Mean & Std. Deviation & & \\
\hline \begin{tabular}{|l|} 
LA \\
BSC
\end{tabular} & $\begin{array}{r}407528.00 \\
8320.40\end{array}$ & $\begin{array}{r}201590.857 \\
3771.242\end{array}$ & 5 & 5 \\
\hline
\end{tabular}

\section{Correlations}

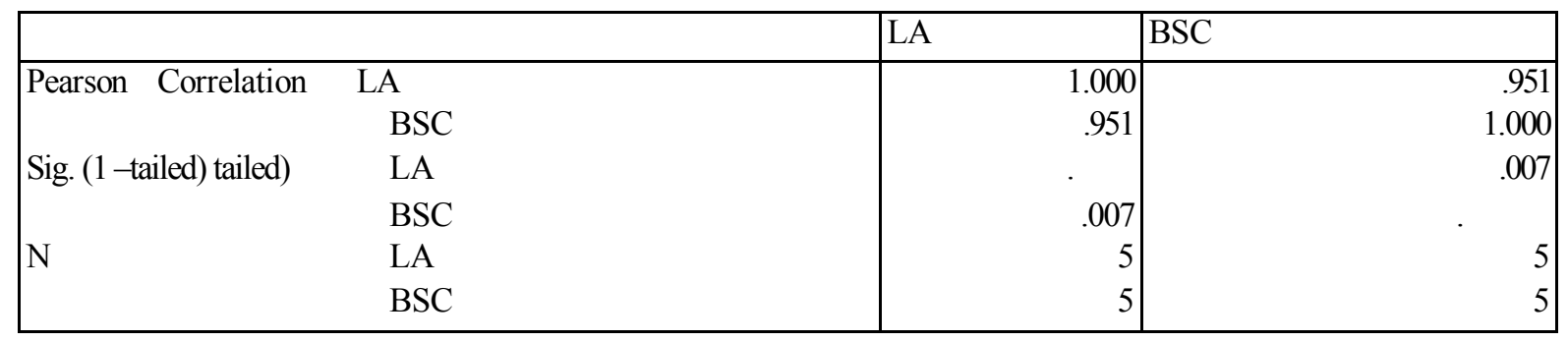

\section{Model Summary}

\begin{tabular}{|l|l|l|l|l|l|l|}
\hline Model & R & R2 & Adjusted R2 & $\begin{array}{l}\text { Std error of } \\
\text { the estimate }\end{array}$ & F change & D.W \\
\hline 1 & $.951 \mathrm{a}$ & .904 & .872 & 72166.221 & 28.2 .13 & 2.338 \\
\hline
\end{tabular}


a Predictors: (Constant), BSC

b Dependent Variable: LA

ANOVA(b)

\begin{tabular}{|ll|l|l|l|l|l|}
\hline Model & Sum of Squares & df & Mean Square & F & Sig. \\
\hline $1 \quad \begin{array}{ll}\text { Regression } \\
\text { Residual } \\
\text { Total }\end{array}$ & 146931604337.191 & 1 & 146931604337.191 & & 28.213 & $.013(\mathrm{a})$ \\
\hline
\end{tabular}

a Predictors: (Constant), BSC

b Dependent Variable: LA

Coefficients(a)

\begin{tabular}{|c|c|c|c|c|c|}
\hline Model & Unstandardized & Coefficients & Standardized Coefficients & $\mathrm{t}$ & Sig \\
\hline & $\mathrm{B}$ & Std. Error & Beta & & Upper \\
\hline $\begin{array}{ll}1 & \text { (Constant) } \\
\text { BSC }\end{array}$ & $\begin{array}{r}-15323.046 \\
50.821\end{array}$ & $\begin{array}{r}85902.457 \\
9.568 \\
\end{array}$ & & $\begin{array}{r}-.178 \\
5.3121\end{array}$ & $\begin{array}{l}.870 \\
.013 \\
\end{array}$ \\
\hline
\end{tabular}

a Dependent Variable: LA 